\title{
A TERMELŐI SZOLGÁLTATÁSOK SZEREPE A HELYI ÉS TÉRSÉGI GAZDASÁG FEJLÖDÉSÉBEN ${ }^{1}$
}

\author{
(The Role of Production Services in the Development of the \\ Local and Regional Economy)
}

\section{GÁL ZOLTÁN - MOLNÁR BALÁZS - NAGY ERIKA}

Kulcsszavak:

termelöi szolgáltatások fejlett üzleti szolgáltatások gazdasági fejlödés térbeli különbségei versenyképesség vállalati kapcsolatrendszerek

Jelen tanulmányban a szerzök a termelôi szolgáltatások egy-egy térség gazdasági szervezeteinek müködésében, fejlödésében, kapcsolatrendszereinek kialakulásában betöltött szerepét elemzik, mutatják be. Megállapitásaikat a Baranya, Fejér, illetve Szabolcs-Szatmár-Bereg megyében, 2001-ben végzett empirikus felmérésre alapozzák, mely kutatás lehetőséget adott arra, hogy a termelöi szolgáltatások terén megmutatkozó területi sajátosságokat, illetve különbségeket bemutassák, megmagyarázzák.

A termelői szolgáltatások a fejlett gazdaságokban a vállalkozások piaci alkalmazkodásának, az azzal járó átalakulási folyamatoknak alapvetỏ tényezói. A keletközép-európai gazdaságokban azonban a szektorban tevékenykedó szervezetek emellett más, nem kevésbé fontos funkciót is betöltöttek, egyrészt a kilencvenes évek elején még hiányzó, alapvető vállalkozási ismereteket közvetítettek, másrészt a nagy számú kisszervezet mủködtetésében is kulcsszerepet töltöttek be, hiszen utóbbiak tőke és emberi erőforrások híján a szolgáltatások csaknem teljes körét kénytelenek voltak externalizálni. A vállalkozások fejlődési pályáját, lehetỏségeit tehát alapvetően meghatározta a rendelkezésre álló szolgáltatások köre, minősége, megújuló-képessége és elérhetősége. Kutatásaink elsósorban a termelői szolgáltatások egy-egy térség gazdasági szervezeteinek müködtetésében, fejlódésében, kapcsolatrendszerének formálásában betöltött szerepére, a szektor helyi-térségi beágyazottságára irányultak. Megállapításainkat három, eltérő fejlődési utat bejáró térségben (Baranya, Fejér és Szabolcs-Szatmár-Bereg megyében) 2001-ben elvégzett empirikus vizsgálatainkra alapoztuk, amelyek segítségével a gazdasági fejlődés néhány új, regionális, illetve települési (falusi, kisvárosi, városi) sajátosságát sikerült feltárnunk.

\section{Strukturális átalakulás, globalizáció és a lokalitás felértékelödése a szektorban}

A termelöi szolgáltatások - a termelés folyamatához közvetve vagy közvetlenül kapcsolódó szolgáltató tevékenységek, melyek fogyasztói gazdasági szervezetek és közintézmények - szerepének felértékelödése a fejlett piacgazdaságok egyik alapvetó strukturális jellemzője volt a nyolcvanas évek elejétől kezdve. A folyamat nemzetközi szinten - a szolgáltatások gyorsan bővülő kereskedelmében -, a nem- 
zetgazdasági mutatókban - a szektor értéktermelésben, foglalkoztatásban betöltött, dinamikusan növekvő szerepében - és a vállalati szférában - a szolgáltató tevékenységek egyre szélesebb körének externalizációjában, s ennek megfelelöen a szolgáltatásokra fordított növekvő költséghányadban - is érvényesült.

A fenti folyamatok mozgatóit, okait a fejlett piacgazdaságokban a nyolcvanas évek elején elindult szerkezeti és szervezeti átalakulásokban kell keresnünk. A vállalkozások gyorsan változó, piaci igényekhez történő alkalmazkodásában, a rugalmas termelési rendszerek kialakitásában, a termék-, technológiai és szervezeti innovációk megvalósításában a szolgáltatók növekvő (meghatározó) szerephez jutottak az elmúlt másfél évtizedben, információ- és tudás-közvetítő, illetve e folyamat - fizikai, humán és egyéb - feltételeinek megteremtése révén. A termelöi szolgáltatások a termelési folyamat valamennyi fázisában megjelentek, növelve a termék hozzáadott értékét azzal, hogy segítették új módszerek, eljárások alkalmazását, javították az elosztás, az irányítás, a marketing és a vállalaton belüli szervezés hatékonyságát. Ezzel hozzájárultak új piacok megszerzéséhez, tőkeforrások bevonásához, termék- és szervezeti innovációk megvalósításához: egészében véve a gazdasági szervezetek versenyképességének javításához. Az externalizációs folyamat elsősorban a standardizált és tőkeigényes szolgáltatásokat (pl. a szállítmányozást és a telekommunikációt), másrészt a speciális tudást és apparátust igénylö tevékenységeket (pl. a hirdetést, műszaki tanácsadást, kutatás-fejlesztést) érintette (Daniels 1991; 1999; Scott-Storper 1993; Delgado 1995; Illeris 1996).

A fejlett üzleti szolgáltatások szükebb csoportjába ${ }^{2}$ tartozó, termelői szolgáltatásokhoz sorolt tevékenységek sajátos csoportot alkotnak: legfontosabb (közös) jellemzöjük, hogy információkat közvetítenek, tehát konzultativ jellegüek, ezért meghatározó szerepet kap az e területen dolgozók szaktudása, tapasztalata, adaptációs (esetleg improvizációs) készsége. A szektorban a kisszervezetek játsszák a meghatározó szerepet, annak ellenére, hogy a kilencvenes években felgyorsult a szervezeti és tökekoncentráció, és növekvö számban jelentek meg az európai piacon a multinacionális szervezetek ${ }^{3}$.

A termelöi szolgáltatások térbeli megjelenését, bizonyos tevékenységi körök - elsösorban a kvalifikált munkaerőt foglalkoztató üzleti szolgáltatások - térbeli koncentrációjának formálódását és tartós fennmaradását, továbbá sajátos térségi/helyi szolgáltatási struktúrák kialakulását a nyolcvanas évek közepétől kezdve a vállalatközi kapcsolatrendszerekbe ágyazottan vizsgálták, s ez a szemlélet a szektorral kapcsolatos későbbi (kilencvenes évekbeli) kutatásokra is hatott. Mig a neoklasszikus közgazdasági iskola megközelítésében az egyes feladatok vállalaton belüli megoldása, illetve külső partnerek bevonása között a tranzakciós kőltségek minimalizálása döntött (Williamson 1985), az újabb felfogás szerint a hálózatépítésben és müködtetésben a ,nem-piaci" tényezök is fontos szerephez jutnak, amelyek részben speciálisak, csak az adott helyre (lokalitásra) jellemzőek is lehetnek (pl. a fizikai infrastruktúra és a társadalmi környezet sajátos elemei kombinációjának eredményeként) (Geenhuisen-Knaap-Nijkamp 1994; Johannisson 1994; Wood 1994). A helyiltérségi kapcsolatrendszerbe ágyazottság tehát pozitiv externáliák forrása, 
melynek fontos eleme a megfelelö tudással és hatáskörrel rendelkezö üzleti partnerek személyes kapcsolatrendszere, illetve az ebben rejlö stabilitás, ami számottevően csökkenti a piaci kockázatot. (Mindez természetesen magában hordozza a túl szoros kötődés és a megmerevedés, illetve a lassú reagálás veszélyét is.) Az intenzív helyi/térségi kapcsolatrendszer másik fontos elönyének - a fejlett telekommunikációs szolgáltatások alkalmazása ellenére - az információk és a tudás formális és informális csatornákon történö - egyformán fontos - áramlását tartják, melynek jelentősége máig megmaradt a vállalati döntéshozatalban. A pénzügyi szolgáltatások esetében pl. az ügyfelekkel való személyes kapcsolattartás mellett az információk gyors és helyes értelmezésében is fontos szerepet kap a szocio-kulturális környezet - melynek fontos elemei az egyes munkatársak személyes kapcsolatrendszere és (esetleg más vállalatoknál, intézményeknél szerzett) szakmai tapasztalatai (Agnes 2000). A tudásintenzív ágazatokban (a kutatásban, fejlesztésben és az azokhoz kapcsolódó szolgáltatásokban) a folyamatos megújulást, a szaktudás áramlását biztosítja a vállalkozók beágyazottsága, intézményekhez, szakmai szervezetekhez és más vállalkozásokhoz füződő - a kutatások szerint erősen strukturált és dinamikus - kapcsolatrendszere (Johanisson 1994). A helyi kapcsolatrendszerböl eredö pozitív externáliákat kihasználva a vállalkozások erösithetik kifelé irányuló (regionális, nemzeti, vagy akár a globális) kapcsolataikat, hosszabb távon átformálva magát a helyi gazdaságot is (Delgado 1995; Daniels 1999).

\section{A termelöi szolgáltató szektor sajátosságai az átalakuló magyar gazdaságban}

A szektor strukturális és szervezeti átalakulása a formálódó kelet-közép-európai piacgazdaságokat sajátos módon érintette. Magyarországon az üzleti szolgáltatások iránti - az évtized elején még kevéssé strukturált - keresletet alapvetően a piaci szabályozó rendszer kialakítása, a társasági törvény elfogadása és az ennek következményeként meginduló cégalapítási hullám, illetve az állami vállalatok átalakítása és privatizációja ösztönözte. A gazdasági szereplök körének átalakulása ugyanakkor a korábbi helyi és térségi gazdasági (vállalatközi) kapcsolatok megszűnéséhez, illetve átrendeződéséhez vezetett. Az új (illetve átalakult) szervezetek müködtetésében és üzleti kapcsolataik felépítésében, formálásában, a helyi/térségi gazdaság kohéziójának kialakitásában a hazai szolgáltató szervezetekre fontos - közvetitő - szerep hárult. A kilencvenes évek második felében ugyanakkor a szektor szereplöinek köre a rugalmas, nemzetközi szolgáltató-hálózatok megjelenésével tovább bővült. A multinacionális szervezetek a helyi munkaerő alkalmazása és képzése révén fontos szerepet játszottak egyrészt a nemzetközi vállalati stratégiák kialakításában és megvalósításában, másrészt a fejlett üzleti szolgáltatások fejlődésében, és azok humán feltételeinek alakításában is (Michalak 1999; Agnes 2000).

Az emlitett folyamatok eredményeként az üzleti szolgáltatások szektorában kialakult kettős struktúra - melynek kínálati oldalát egyrészt a nemzetközi ügyfélkörrel és kiterjedt információs háttérrel rendelkezö szolgáltatók, másrészt a helyi, esetleg 
regionális piaci kapcsolatokkal rendelkező, túlnyomórészt rutinjellegủ szolgáltatásokat biztosító kisszervezetek alkotják - nem csupán az átalakuló gazdaságokra jellemzỏ sajátosság. Feltevésünk szerint azonban ez a dualizmus jóval nagyobb különbségeket takar - ágazati, szervezeti és földrajzi szempontból is -, mint a fejlett piacgazdaságok esetében. Ennek legfontosabb oka a keresleti oldalon - a kis- és mikrovállalkozások túlnyomó többségénél - jelentkező tőkehiány. A gazdasági szempontból leszakadó-stagnáló térségekben a kisszervezetek túlnyomó többségének fejlődési pályája - melynek legfontosabb állomásainál van a legnagyobb szükség „külső" szolgáltatók segítségére - kifejezetten szegényes szolgáltatói háttér kialakulását ösztönözte. Ugyanakkor a viszonylag csekély számú, speciális (elsősorban fejlett üzleti) szolgáltatást nyújtó szervezet ezért térben erősen koncentráltan jelenik meg és túlnyomórészt (nagy-)városi székhelyủ szervezetek keresletére építkezik.

A kereslet strukturális egyoldalúságából, illetve térbeli differenciálódásából következően a szektor regionális kohéziós szerepe viszonylag gyenge. Feltételezésünk szerint a kilencvenes évek második felében meginduló növekedés és strukturális átalakulás, a vállalkozások múködési (makrogazdasági-szabályozási) feltételeinek stabilizálódása azonban a helyi (városkörnyéki) gazdaság kohéziója szempontjából kedvezö folyamatokat is elinditott. Ebben fontos szerepet töltöttek be a szolgáltató szervezetek is, melyek piaca ugyan jelentősen bővült, ez azonban a térségek és a városhierarchia további differenciálódását ösztönözte. Úgy tünik azonban, hogy még az intézményi ellátottság és a képzett munkaerő szempontjából legkedvezőbb helyzetủ vidéki centrumokban (felsőoktatási-kutatási központokban) kialakuló struktúra is erősen hiányos, nem jelentek meg pl. a tudás-intenziv ágazatok fejlödéséhez szükséges (információkat, tudást közvetítỏ és befektetőket mozgósítani képes) szolgáltatások.

A vázolt hiányosságok ellenére, a gazdasági növekedés megindulásának eredményeként egészében véve mégis strukturáltabbá vált a termelöi szolgáltatások piaca az elözö évtized végére. Feltevésünk szerint - a nyugat-európai sajátosságokhoz hasonlóan - a felhasználók köre vállalati méretek szerint differenciálódott elsősorban. Közöttük legnagyobb súllyal (az igénybe vett szolgáltatások értékét tekintve) a középvállalkozások jelentek meg, akiket a velük szemben támasztott minőségi követelmények - beszállítói kapcsolataik, illetve a nemzetközi piaci megmérettetés ösztönöztek a szolgáltatások széles körének igénybe vételére. A nagyvállalatok viszont jóval több feladatot oldanak meg ,házon belül” (internalizálják azokat), nagy kockázattal járó, stratégiai lépések esetén támaszkodnak külső szolgáltatókra, elsősorban ismert (hazai vagy nemzetközi) nagyvállalatokra. A kisvállalkozások megfelelő szellemi kapacitások hiján - legtöbbször a rutinszerủ feladatokat is ,külsősökkel" (többnyire helyi szolgáltató kisvállalkozások segítségével) oldják meg, mivel a belső - állandó - munkatársak alkalmazása túl költséges. Feltesszük továbbá, hogy emellett az ágazati sajátosságok, valamint a vállalkozások kapcsolatrendszere (különösen a nemzetközi kapcsolatok megléte/hiánya) is erősen befolyásolják a kereslet alakulását. 
Az átalakuló magyar gazdaság termelői szolgáltatási piaca sajátosságainak, a szektor helyi és térségi gazdaságban betöltött szerepének, valamint területi különbségeinek vizsgálatát empirikus módszerekkel, illetve (kiegészítésképpen) statisztikai adatok elemzésére támaszkodva végeztük el. A kiválasztott célterületek - Fejér, Szabolcs-Szatmár-Bereg és Baranya megye - a kilencvenes évtizedben eltérö fejlödési pályán mozogtak, és a szektorban meghatározó szerepet betöltő megyeszékhelyek fejlödési feltételei, illetve üteme is jelentősen eltért. Felhasználói kérdőíveinket mindhárom megyében azonos tartalommal küldtük ki, $\mathrm{s}$ a beérkezett, több mint 200 értékelhetố válasz révén képet alkothattunk a megyeszékhelyeken, a kisvárosokban és a falvakban múködö vállalkozások szolgáltatásokkal kapcsolatos igényeiről, annak változásáról, a szolgáltatásoknak a vállalkozások mủködtetésében és a stratégiai átalakításokban betöltött szerepéröl, továbbá a felhasználó-szolgáltató kapcsolatrendszer múködési mechanizmusáról és térbeliségéről, illetve - a térkapcsolatokkal összefüggésben - az elektronikus szolgáltatások szerepéről is. A szolgáltatókkal készitett interjúk elemzésével betekintést nyertünk a szektor formálódásának folyamatába (az alapítás körülményei és feltételei, stratégiai váltások a felmérés időpontjáig), mủködésébe (infrastruktúra, személy feltételek). Az interjủk legfontosabb elemei azonban a szolgáltatók helyi gazdaságba való beágyazottságára (ügyfélkörük alakulása, sajátosságai), térkapcsolataira és a szektor egészéről kialakított véleményére vonatkozó kérdések voltak. A felkeresett szervezetekre vonatkozó, alapvetó információk (vállalkozás mérete, tevékenysége, alapítás időpontja, éves árbevétel nagyságrendje) mind a felhasználók, mind a szolgáltatók esetében segítette a termelói szolgáltatások helyi/térségi piaca strukturális jellemzóinek pontosabb meghatározását.

\section{A szektor súlya a vizsgált térségek gazdaságában}

A termelői szolgáltatások fejlettsége, struktúrảja, illetve a nemzetgazdaság teljesítménye erösen korrelál (Daniels 1999). A magyarországi térségekre vonatkozó vizsgálataink szerint a gazdasági aktivitás és az ipari kibocsátás mellett a kvalifikált munkaerő eloszlása is befolyásolta a szektor fejlődését, dinamikáját, illetve annak térbeli különbségeit. A termelői szolgáltatások köre bövưlésének és szereplöi gyarapodásának eredményeként a szektor hozzájárulása az értéktermeléshez növekedett a kilencvenes évek második felében. A folyamat térbeli sajátosságait alapvetöen befolyásolta a korábban - az évtized közepére - kialakult térstruktúra, azonban ennek új, elsősorban a vidéki nagy- és középvárosok köréből kiemelkedő elemei is megjelentek, amelyek érintették az általunk vizsgált térségeket is.

Fejér megyében, ahol a gazdasági növekedés mozgatója a külföldi tőke bevonásával történö, export-orientált ipari szerkezetváltás, a termelöi szolgáltatások szektorának növekedése a vidéki átlagnál jóval dinamikusabb volt, és a folyamat strukturált, sokoldalú termelői szolgáltató szféra kialakulását eredményezte. Ennek ellenére - elsősorban az ipar nagy súlya miatt - a termelői szolgáltatások hozzájárulása a megyei gazdaság kibocsátásához elmarad a megyék átlagától. Ugyanakkor erősöd- 
tek a szektor megyén belüli területi különbségei az iparosodó városi térségek javára, illetve a megye középső-déli területeinek rovására. A megyeszékhely szerepe meghatározó a termelői szolgáltatások térszerkezetében - különösen a számítástechnikai, müszaki tanácsadási és fejlesztési, illetve a gazdasági-piaci információkat közvetítő tevékenységek esetében --, de Budapest közelsége ezt a dominanciát számottevően csökkenti a megye keleti részén.

A leszakadó térségek közé sorolt Szabolcs-Szatmár-Bereg megyében közvetve (szellemi potenciál, vállalkozói kultúra) és közvetlenül is (a felhasználók köre, összetétele) a térség gazdaságának szerkezeti és szervezeti sajátosságai határozták meg a szektor struktúráját (a tartósan gyenge vállalkozási aktivitás, a mikrovállalkozások magas aránya, a tőkefelhalmozás alacsony szintje, az infrastruktúra hiányosságai, a gyenge iparosodottság, a sikeresen privatizálható, megújulásra képes nagyvállalatok csekély száma). Bár a kilencvenes évtized végén dinamikusan nőtt a szolgáltatók száma, illetve jelentős részük bővítette tevékenységi körét - különösen a jogi, adó- és ügyviteli tanácsadás, az ingatlanügyletekhez kapcsolódó szolgáltatások és az informatikai, valamint irodatechnikai tevékenységek irányába -, a megye vidéki összehasonlításban mégis gyenge fajlagos (szolgáltatók ezer vállalkozásra jutó száma) és abszolút (pl. egyes termelői szolgáltatások megjelenése/hiánya) mutatókkal jellemezhető. Ugyanakkor a szektor - és annak dinamikája - megyén belüli rendkívül erős térbeli (nyíregyházi) koncentrációja önmagában is piaci hátrányt jelent a megyeszékhelytől távolabb fekvő településeken müködő vállalkozások számára, $\mathrm{s}$ elörevetíti a peremterületek további leszakadását.

Bár Baranya megye nem sorolható a gazdasági szempontból dinamikus térségek közé, a termelöi szolgáltatások struktúráját, sokoldalúságát tekintve azonban nem tekinthető leszakadónak sem. A kedvezỏ mutatók hátterében azonban a szolgáltatások hagyományosan erös pécsi koncentrációja áll. A város a legnagyobb vidéki termelői szolgáltató bázissal rendelkező centrumok közé tartozik, továbbá rendelkezik a tudásalapú gazdasági fejlödéshez szükséges intézményhálózattal és humán erőforrásokkal. A gazdasági mutatók és a korábbi elemzések (Horváth 1994; Gál 2000) alapján azonban abból a feltevésböl indultunk ki, hogy mindez sajátos, kettős szerepet eredményez Pécs esetében. Míg ez utóbbi fejlődési pályán nem indulhatott el a város, mivel alapvetö feltételek - többek között a fejlett üzleti szolgáltatások néhány eleme - hiányoznak hozzá, a termelő szolgáltatások szférájában Pécs „rátelepszik" megyéjére, ami a peremhelyzetú településeken a szabolcsihoz hasonló feszültségeket eredményez, s mindez - feltevésünk szerint - a vállalati kapcsolatrendszereken keresztül (szolgáltatók - felhasználók) is mérhetö.

\section{A termelöi szolgáltatások piacának strukturális sajátosságai a mintaterületeken}

Felmérésünk szerint a szektorban a kilencvenes évek második felében lezajló szerkezeti átalakulást alapvetően a kereslet bövülése és átstrukturálódása ösztönözte. Mindhárom mintaterületen a vállalkozások müködtetéséhez szükséges pénzügyi, 
biztosítási, számviteli és könyvvizsgálói szolgáltatások iránti igény volt a legnagyobb. A legdinamikusabban ugyanakkor az információs technológiák és a fejlettebb irodatechnikai eszközök alkalmazásához kapcsolódó tevékenységek (telekommunikációs, irodatechnikai szerviz, hardver- és szoftver-szolgáltatások), továbbá a hirdetési és reklám-szolgáltatások iránti kereslet bövült.

A kereslet alakulása azonban erősen strukturált volt a felhasználók árbevételének, tevékenységének és székhelyének (régió és településtípus) függvényében. A kis- és mikrovállakozások többsége csupán a legfontosabb, a fennmaradáshoz elengedhetetlen szolgáltatásokat veszi igénybe mindenhol, számukra még ezek is nehezen elviselhető pénzügyi terhet jelentenek. Többségük kisvárosi, illetve falusi székhelyü vállalkozás, melyek célja általában a családi vállalkozás fennmaradása, a túlélés.

A középvállalkozások és a dinamikus, fejlödö kisszervezetek (túlnyomórészt a 100 M Ft-nál nagyobb árbevételt elérők) jelentik a piac legszínesebb csoportját. A termelői szolgáltatásokat elsősorban a piaci alkalmazkodás, terjeszkedés, illetve stratégiai partnerek felkutatása céljából veszik igénybe. E cégek a vállalkozás fejlesztéséhez, átalakításához, versenyképességük növeléséhez szükséges jogi- és adótanácsadás mellett a piackutatási, oktatás-képzési szolgáltatásokat is keresik. Tevékenységi körök (ágazatok) szerint is tapasztalható strukturális eltérés a keresletben. Az információáramlással kapcsolatos szolgáltatásokat leggyakrabban más szolgáltatók veszik igénybe, míg a szállítmányozási-logisztikai szolgáltatásokat többnyire kereskedelmi és ipari vállalkozások keresik. Az ipari és szolgáltató szervezetek eltérő piaci kapcsolatrendszere és szolgáltatásokkal kapcsolatos igényei Fejér megyében különültek el a legélesebben. Az elöbbiek a bel- és külfơldi piaci expanzióhoz kapcsolódó szolgáltatások keresleti oldalán töltenek be meghatározó szerepet, míg a szolgáltató kisszervezetek a helyi/térségi piaci igényekhez történő rugalmas és gyors alkalmazkodáshoz (új üzleti stratégia kialakításához) veszik igénybe más szervezetek szolgáltatásait.

A legélesebben két sajátos csoport különül el a többi vállalkozástól. Az egyik a külföldi kapcsolatrendszerrel rendelkezỏ szervezeteké, amelyek a terjeszkedés, kapcsolatteremtés és -müködtetés töke- és információigényes folyamatában a jogi-, pénzügyi, üzletviteli, külföldi szállítmányozási, fordítói, vámügyi szolgáltatások jelentős költségeit képesek vállalni. A külpiaci kapcsolatok építése egyik akadályának éppen e tevékenységek kényszerủ externalizációja és magas költségei tủnnek, amihez - nyugati export esetén - hozzáadódnak a minőségbiztositás terhei. E kơr bỏvülése a vizsgált térségek közül a kapcsolati tőke és a földrajzi közelség elönyeit kihasználó Fejér megyei - elsősorban a két nagy ipari centrumban müködő - vállalkozások körében figyelhetö meg, a másik két térségben az ide sorolható szervezetek inkább kivételnek számítanak.

A felhasználók sajátos, a Fejér megyei, valamint a pécsi gazdaságban is csupán szórványosan megjelenö csoportját alkotják a kutató és fejlesztő intézményekkel, szervezetekkel kapcsolatban álló vállalkozások. A szolgáltatások e csoportja iránt a legcsekélyebb a kereslet, még Pécsett is rendkívül gyenge a vállalkozói szféra és az intézmények kapcsolata mind a $\mathrm{K}+\mathrm{F}$, mind az oktatás-képzés területén, amely - 
más tényezőkkel együtt - az eredmények városi (és régión) kívüli hasznosulását eredményezi. A számítástechnikai és müszaki tanácsadási szolgáltatásokkal - a vidéki nagyvárosokhoz viszonyitva - jól ellátott, stabil ipari háttérrel rendelkezö Székesfehérváron a kapcsolatrendszer hiányosságai más összefüggésben, az ipar (hosszú távon fenntartható) versenyképességének és az egyoldalú kapcsolatokból eredő sebezhetőség problémájaként jelennek meg, míg Szabolcsban ez a csoport gyakorlatilag hiányzik. Ezek a problémák más-más típusú beavatkozást is igényelnek, de valamennyi összefügg a termelö szolgáltatások helyi/térségi struktúrájával, annak gyengeségeivel és hiányosságaival.

Mindhárom vizsgált térségben jól elkülönülnek tehát a statikus és dinamikus fogyasztói (vállalkozási) csoportok aszerint, hogy mennyi, milyen típusú szolgáltatást, milyen - stratégiai vagy müködtetési - célra, mekkora gyakorisággal vesznek igénybe, és keresletük hogyan változott az elmúlt négy-öt évben. A szerény árbevételü - sok esetben családi - kisvállalkozások elsősorban a rutinszerü, mủködetést szolgáló szolgáltatások iránti tömeges igényt növelték, míg a közép- és nagyvállalkozások, valamint a piaci változásokra rugalmasan reagáló, terjeszkedö - különösen a külpiaci kapcsolatokat építő - kisvállalkozások a termelői szolgáltatások körének bővülését és differenciálódását ösztönözték. A vizsgált régiókban zajló gazdasági folyamatokat hủen tükrözi a szolgáltatások iránti kereslet alakulása. Míg Szabolcsban a müködöképességen van a hangsúly, Pécsett a helyi/térségi igényekhez történő alkalmazkodáson (erre utal pl. a tevékenységi kör átalakítása a szolgáltatóknál), Fejérben pedig e célok mellett nagyobb hangsúlyt kapott a nagyvállalatokkal kialakítandó partnerség, továbbá a termék- és technológiai innovációk megvalósításához szükséges szolgáltatások iránti igény.

Valamennyi vizsgált térség vállalakozásairól elmondhatjuk általában, hogy egyre többféle szolgáltatást vesznek igénybe versenyképességük javításához, a piackutatástól és a jogi, illetve adótanácsadáson, valamint a reklámon át a telekommunikációs-információs technológiák alkalmazásához kötődő tevékenységekig. A szolgáltatásokhoz kötődő innovációs „hajlandóság” azonban a fentebb említett szervezeti és ágazati sajátosságok mellett erősen tagolódik a vállalkozások székhelye szerint: a megyeszékhelyen, illetve a jelentős ipari és szolgáltató bázissal rendelkező középvárosokban müködỏ gazdasági szervezetek kereslete a legstrukturáltabb, legsokoldalúbb, még a kisvállalkozói kör is jóval több és többféle szolgáltatást vesz igénybe, mint a nagyobb árbevételủ, községi és kisvárosi székhelyüek. A szolgáltatások piacának e sajátosságát hipotézisünkben a vállalkozások helyi/térségi kapcsolatrendszerbe ágyazottságával és az abból eredö pozitív hozadékokkal (externáliákkal) magyaráztuk. Felmérésünkben ezért kitértünk a szolgáltató szervezetek kapcsolati hálójának elemzésére, annak térségi sajátosságaira is.

\section{A termelöi szolgáltatások helyi/térségi gazdaságban betöltött szerepe}

A szolgáltatók mindhárom vizsgált térségben a szabályozók változását, a gazdasági szerkezet átalakulását és a vállalkozások gyarapodását tekintették a legfontosabb ösztönzőnek alapitásukkor. A vállalkozás inditásában és múködtetésében is 
Tér és Társadalom 16. évf. 2002/2. 113-128. p.

fontos szerepet játszott egyrészt az alapítók iskolázottsága és személyes tapasztalatai ${ }^{4}$, másrészt a rendszerváltás elött kialakult személyes kapcsolatrendszerük. Ez utóbbi meghatározó szerepet játszik a szolgáltató és felhasználó közötti üzleti kapcsolatok megteremtésében, különösen a megyeszékhelyeken müködő felhasználók esetében. Az Internetet és a cégkatalógusokat viszonylag kevesen veszik igénybe erre a célra, míg helyi (személyes) kapcsolatrendszerrel nem rendelkező, külföldi érdekeltségü vállalkozások, valamint a városi székhelyü, elsősorban az iparban tevékenykedő kőzép- és nagyvállalatok (elsősorban Fejér megyében), továbbá a kőzségi székhelyủ szervezetek - a városokban koncentrálódó szolgáltatásokkal kapcsolatos információk hiján - gyakrabban veszik igénybe szakmai szervezetek segítségét. Az informális mechanizmusok különösen nagy szerepe részben a piaci kockázat minimalizálására való törekvésböl ered, részben azonban - tekintettel döntő súlyára a kapcsolatteremtésben - a rendszerváltás termékének kell tekintenünk a jelenséget ${ }^{5}$. Ugyanakkor sok esetben a „megbízhatóság” a szakmai szempontok rovására érvényesưlhet, ami a felhasználó szempontjából piaci hátrányt eredményez (pl. kevesebb vagy kevésbé friss információt). Ezért egyrészt komoly problémának tartjuk a minősitési rendszerek lassú terjedését a szolgáltató szektorban, továbbá az igénybe vehetô szolgáltatásokkal kapcsolatos információk hiányát, elsösorban a falusi-kisvárosi terekben.

A termelöi szolgáltatások körében is élesedő versenyre adott válaszként azonban mind több szolgáltató igyekszik a helyi tematikus cégkatalógusokban is regisztráltatni magát, s emellett néhány cég az ügyfélkör bővítésére az Internetet is igyekszik felhasználni. Akadnak ugyanakkor - egyelöre szórványos és városokban koncentrálódó - példák olyan szervezetek müködésére is, amelyek a szolgáltatásokkal kapcsolatos információk terjesztésével próbálják ösztönözni a helyi gazdaság szerkezetének megújulását. ${ }^{6}$

A szolgáltató szervezetek helyi/térségi gazdaságba való beágyazottságát tükrözi ügyfélkörük alakulása. A szolgáltató szektorbeli vállalkozások többségének igen széles körü az ágazati kapcsolatrendszere. Néhány, speciális szolgáltatást nyújtó cég (pl. biotechnológia, környezetvédelem, müszaki és szoftverfejlesztés) viszont egy-egy szektorális csoporttal (egészségügy, energiaszektor, feldolgozóipar) áll csak kapcsolatban, közöttuik pedig döntő súllyal vannak jelen a nagy- és középvállalatok. E szolgáltató szervezetek erősen strukturált szakmai és üzleti kapcsolatrendszerrel rendelkeznek, de erősebben függnek (kevesebb számú) partnereik megrendeléseitől.

A ritkábban igénybe vett, információközvetítéssel, szervezéssel kapcsolatos szolgáltatások (számítástechnika, piackutatás, hirdetés) ügyfélkörében az iparban és a termelői szolgáltatásokban tevékenykedő, jelentősebb tőkével és $100 \mathrm{M} \mathrm{Ft} \mathrm{feletti}$ éves árbevétellel rendelkező kis- és középvállalkozások túlsúlya a jellemző. A szolgáltatások ezen csoportjában a városi székhelyü (elsősorban megyeszékhelyen müködő) szervezetek teszik ki a kereslet túlnyomó részét (50-80\%-át), amely utal a vizsgált térségek - különösen Baranya és Szabolcs-Szatmár-Bereg megye - gazda- 
ságában erősödő szerkezeti kettősségre, divergenciára (szolgáltató megyeszékhely ipari és mezőgazdasági kisvállalkozások fejlődésétől függő kisvárosok és falvak).

A legszélesebb ügyfélkörrel a pénzügyi, biztositási, könyvvizsgálói és számviteli szolgáltatásokat nyújtó szervezetek rendelkeznek, melyek gyors elérhetőségét biztosítják a túlnyomórészt városokban tömörülö, jól elérhetö telephelyeik, irodảik. Ezek ügyfélköre ágazati és szervezeti szempontból a legösszetettebb, de domináns közöttük a kis- és a középvállalkozások csoportja, amelyek általában heti többszöri rendszerességgel veszik igénybe szolgáltatásaikat. A szolgáltatókkal készített interjúkból kiderült, hogy a szektornak ez a szegmense meglehetősen zárt: a vállalkozások (felhasználók) általában „helyi” szolgáltatókat keresnek fel igényeikkel, ugyanakkor a szolgáltatók külső kapcsolatrendszere gyenge, elsősorban a városkörnyékre fókuszált.

Az üzleti szolgáltatások aránya az egyes szervezetek ráforditásaiban tükrözi a vizsgált térségek szervezeti és ágazati struktúráját. A legkevesebbet (ráfordításaik kevesebb, mint $10 \%$-át) a szolgáltatások nagy hányadát „házon belül” megoldó nagyszervezetek és a mikrovállalkozások ${ }^{7}$ (minimális igények) fordítják ilyen célra. A legtöbb esetben a ráfordítások aránya $11-20 \%$-os, $s$ többnyire a méreteik miatt externalizációra kényszerülö kis- és középvállalkozások tartoznak ide. A csoporton belül ágazati szempontból a szabolcsi, illetve a pécsi mintában a szolgáltatások túlsúlya jellemző, Fejér megye esetében viszont az ipar nagyobb súlya a keresleti oldalon is érvényesül.

A termelöi szolgáltatások közül a legnagyobb tételt a vállalkozások kiadásai között a telekommunikáció, a pénzügyi szolgáltatások és a szállítmányozás (valamint a kereskedelmi szervezeteknél a nagykereskedelmi-elosztó tevékenységek) jelentik a vizsgált térségekben. A kisvállalkozások tömeges keresletének eredményeként ezeket a számviteli és könyvvizsgálói szolgáltatások, majd a bövülö piaccal rendelkező hirdetési és reklámszolgáltatások követik. Különösen nagy költségterhet jelent a termelöi szolgáltatások igénybe vétele azon szervezetek számára, amelyek információk és áruk áramlására építik tevékenységüket (pl. az informatikai és külkereskedelmi tevékenységet folytató cégek), vagy pedig (tevékenységüktöl függetlenül) falvakban müködö mikroszervezetek, amelyek szerény forgalmukhoz viszonyítva nagy „rezsivel” dolgoznak. Ez utóbbi csoport számára létkérdés az adminisztrációhoz kapcsolódó terhek (szolgáltatási költségek) csökkentése. A szolgáltatások magas költségei ugyanakkor magyarázattal szolgálnak arra is, hogy az elaprózott szervezeti struktúrával és tőkehiánnyal, valamint a feldolgozóipar lassú szerkezeti átalakulásával jellemezhető térségekben (pl. Baranyában és Szaboles-Szatmár-Bereg megyében) müködő vállalkozások külső (elsösorban külföldi) kapcsolatrendszere miért szórványos és formálódik vontatottan. Ezek a szerkezeti sajátosságok befolyásolják a termelői szolgáltatások további fejlődését is: a pécsi és nyíregyházi szolgáltatók szerint a helyi/térségi vállalkozások javuló teljesítménye alig hatott ösztönzöleg a szektor fejlödésére, ök jelenleg is a közepes nagyságú ipari vállalkozások kis számát és gyengeségét tartják a tercier szektor egyik fejlődési gátjának. A termelői szolgáltatásokat nyújtó cégek a piaci versenyképesség növelésére Fejér 
megyében is elsősorban a megye ipari központjaiban vannak kedvezỏ hatással (Székesfehérvár, Dunaújváros), tevékenységükkel különösen a helyi vállalkozások megújuló képességét segítik. A két nagy ipari centrumban koncentrálódó humán tôke - a magasan kvalifikált közgazdasági, müszaki, pénzügyi-számviteli szakemberek, akik sok esetben több szakvizsgával is rendelkeznek - révén vált a szektor a megye iparának (és szolgáltató szektorának) egyik fontos, dinamizáló tényezỏjévé.

\section{A szolgáltatások helyi beágyazottsága és struktúrája a megyeszékhelyeken}

Felmérésünk szerint a képzett munkaerőt és a termelői szolgáltatások széles körét biztosító, megyeszékhelyeken müködö gazdasági szervezetek vállalati kapcsolatrendszere a legsürübb és legstrukturáltabb, amelyben fontos szerepet töltenek be a (piaci) szolgáltatásokat nyújtó szervezetek. Mindhárom mintaterületről elmondhatjuk azonban, hogy ha formálódnak is több vállalkozást átfogó kapcsolatrendszerek a helyi gazdaságban, ezek fókuszában nem a termelö szolgáltatások állnak. A szabolcsi megyeszékhely gazdaságára szervezeti szempontból az atomizáltság jellemző, a szervezetek többségének célja a túlélés, kapcsolataik a szolgáltató szektorral korlátozottak. Ennek eredménye a szektor egyik fontos strukturális gyengesége, a müszaki fejlödést és az innovációk terjedését segitô szolgáltatók $(\mathrm{K}+\mathrm{F}$; nem épitészeti jellegü múszaki tanácsadás) szerény száma, valamint az üzleti információk gyors áramlását (pl. EU minőségi normák, EU- és kormányzati támogatási lehetőségek, piaci információk, befektetési lehetőségek, vállalkozási övezetekkel kapcsolatos ismeretek) elösegitö szolgáltatások fejletlensége. Ez utóbbi részben a szektor gyenge pontjaira (marketing, piackutatás), részben a már müködỏ szervezetek (ügyviteli tanácsadás, számviteli szolgáltatások) tevékenységének hiányosságaira vezethetö vissza.

Pécsett a magasabb szintủ, minőségi szolgáltatást nyưjtó pénzügyi-, jogi-, befektetési-, pályázati- és PR-tanácsadás, a piackutató, közvélemény-kutató, informatikai (Dravanet, High-Computer cégcsoport), a high-technológia körébe tartozó bio- és lézertechnológiai $\mathrm{K}+\mathrm{F}$ szolgáltatási kapacitás is fejlettnek mondható vidéki nagyvárosi viszonylatban. A helyi szolgáltató szektorról a szolgáltató vállalkozások közel $60 \%$-a ugyan megelégedettséggel beszélt, de mintegy negyedük a szektor helyi hiányosságait hangsúlyozta, legtöbben a logisztika, a számítástechnikai-, alkalmazott informatikai szolgáltatások, a közlekedés, a $\mathrm{K}+\mathrm{F}$ és a müszaki innovációs szolgáltatások hiányosságait emelték $\mathrm{ki}^{8}$. A Pécsett nagy számban található jelentős szellemi kapacitásokat tömöritő intézmények kapcsolatai kifelé mutatnak és szórványosak a helyi gazdasági szereplőkkel, a szolgáltatók pedig saját fejlődési lehetőségeiket nem az előbbiekkel, hanem az ipari átalakulással (beruházásokkal) összefüggésben értelmezik. A helyi gazdaság kohéziójának erősítését nem segíti az sem, hogy a pénzügyi szolgáltatók üzleti stratégiájukat nem városokra/térségekre, illetve az ott mủkődỏ vállalkozások igényeire szabottan dolgozzák ki, $\mathrm{s}$ az emiatt állandósuló tỏkehiány a közép- és kisvállalati szektor helyi és nemzetközi kapcsolatainak épitését is gátolja. 
A Fejér megyei ipari centrumokban formálódó vállalati kapcsolatrendszerek középpontjában ipari nagyszervezetek állnak. Ez utóbbiak a termelöi szolgáltatások nagy részét „házon belül” oldják meg, de megjelennek fogyasztóként is a kutatásfejlesztés, műszaki szaktanácsadás, piackutatás, logisztika piacán. A hozzájuk kötődỏ kis- és középvállalkozások ugyanakkor a helyi szolgáitatási piac más elemei (pl. a rutinjellegü szolgáltatások) iránti keresletet növelik, ami sajátos, kettős piaci struktúra kialakulását eredményezte. A helyi gazdaság ágazati sajátosságainak eredményeként Dunaújvárosban viszonylag zárt szolgáltatói piac formálódott (a helyi vállalkozások zöme helyi szolgáltatókat keres fel igényeivel) a város szolgáltató szektorának strukturális hiányosságai ellenére, melyek a kutatás-fejlesztés, a logisztika, a piackutatás terén jelentkeznek elsősorban. A megyeszékhely vállalkozásai - különösen a szolgáltató szektorban tevékenykedők, valamint a dinamikus, feldolgozó-ipari kis- és középvállalkozások - viszont nyitottabb, az észak-dunántúli nagyvárosokra és Budapestre is kiterjedő kapcsolatrendszerrel rendelkeznek. Ez a tény, továbbá Székesfehérvár szolgáltató szektorának erösségei (pl. számítástechnikai szolgáltatások, müszaki tanácsadás) arra utal, hogy folyamatosan bővül azoknak a vállalkozásoknak a köre, amelyek igyekeznek megfelelni a beszállítókkal, alvállalkozókkal kapcsolatos igényeknek (minőségbiztositás, magas szintü szervezés, számítástechnika alkalmazása az ügyvitelben stb.) (Döry 1998), s ebben külső szolgáltatókra támaszkodnak. Erre utal a számítástechnikai szolgáltatások, a műszaki tanácsadás, továbbá a piaci információk áramlásával kapcsolatos tevékenységek gyarapodása a városban.

\section{A szolgáltatók térségi kapcsolatrendszere}

Mindhárom vizsgált térségben meghatározó szerepet töltenek be a megyeszékhelyen tevékenykedő szolgáltatók a megye többi településén müködő vállalkozások ellátásában. A három nagyváros szerepe különösen pénzügyi, számítástechnikai, piackutatási, reklám- és hirdetési szolgáltatásokban meghatározó, térkapcsolataik azonban csak egy-két esetben nyúlnak túl megyéjük határain. A kínálat mellett azonban a termelő szolgáltatások iránti kereslet is erösen koncentráltan jelentkezik a vizsgált megyékben. Mivel a felhasználók általában helyi szolgáltatókat keresnek fel ügyviteli tanácsadás, számviteli és könyvvizsgálói szolgáltatásokkal kapcsolatos igényeikkel, ez egyrészt a „rutinjellegü” szolgáltatások iránti igények városivároskörnyéki tömörülésében jelentkezik, másrészt a megyeszékhelyeken működő szervezetek nagyobb „hajlandóságával” a szolgáltatások szélesebb körének - illetve új típusainak - felhasználására. A megyeszékhelyeken mủködő, termelői szolgáltatásokat nyújtó vállalkozások ügyfelei 55-70\%-ban helyi, illetve városkörnyéki felhasználók közül kerülnek ki.

A három nagyváros szolgáltató szektorának strukturális hiányosságait jelzi a felhasználók külsö kapcsolatrendszerének kiterjedése és tartalma. Ilyen szempontbó! a három megyeszékhely három önálló típust testesít meg. Budapest mindhárom esetben fontos szerepet tölt be a szállítmányozásban, a logisztikai és a műszaki fejlesz- 
téshez kapcsolódó, továbbá a piackutatási, reklám- és speciális szoftverszolgáltatásokban, illetve az oktatásban. A fővárosi szolgáltatókkal a megkérdezett vállalkozások mintegy tizede rendszeres - általában heti - kapesolatban áll. A fővárosi kapcsolatrendszer fókuszában szinte kivétel nélkül városi székhelyủ - túlnyomórészt megyeszékhelyen múködő vállalkozások állnak, jelentős részük több telephellyel és külföldi piaci kapcsolatokkal is rendelkezik. Ez utóbbiak müködtetéséhez tehát többnyire nem elégségesek a helyi szervezetek által nyújtott szolgáltatások.

A Fejér megyei vállalkozások közül jóval több számára fontos a budapesti kapcsolat, különösen a feldolgozóiparban tevékenykedö, illetve a megye keleti részén mủködỏ szervezetek számára. A térségben múködỏ szervezetek kapcsolatai emellett Győr és (csekélyebb számban) Veszprém felé irányulnak. Pécset ezzel szemben a fővárostól való távolsága, valamint sokoldalú szolgáltató szektora egyértelmúen domináns szerephez juttatta megyéjében, és néhány ágazatban - pl. a szállítmányozásban, a számítástechnikában és a piackutatásban - regionális, illetve országos, a kutatás-fejlesztésben múködő pécsi vállalkozások pedig nemzetközi kapcsolatrendszert építettek ki. Ugyanakkor a feldolgozó-ipari szerkezetváltáshoz elengedhetetlen szolgáltatásokat (mủszaki tanácsadás és fejlesztés, speciális pénzügyi szolgáltatások) hiányolták a helyi szervezetek. Ez is arra utal, hogy a város gazdasági bázisa biztosítja Pécs helyét a vidék legnagyobb szolgáltató centrumai között, de ez önmagában még nem ösztönözte eddig a város tágabb térségét is (kedvezően) érintỏ ipari átalakulást. Nyíregyháza is meghatározó szerepet tölt be megyéjében, de az itteni szolgáltatók térkapcsolatai - csekély számú kivételtól letekintve - véget érnek a megye határainál. Debrecen és Miskolc alapvetően regionális elosztó centrumként fontos a szabolcsi vállalkozók számára, szerepük az oktatásban, kutatásban, információközvetítésben szórványos. Szellemi potenciáljuk tehát kihasználatlan, ami a vizsgált térség ipari bázisának gyengeségeivel és munkaerő-piaci sajátosságaival magyarázható.

A vizsgált térségek kisvárosai fontos szerepet töltenek be a napi-heti rendszerességgel igénybe vett, a vállalkozások múködését biztosító szolgáltatásokban. A kisvárosokban elérhetó biztositási, pénzügyi, jogi és számviteli szolgáltatásokat igénybe veszik a helyi vállalkozók, de a reklámmal, piackutatással, adótanácsadással és irodatechnikai szolgáltatásokkal kapcsolatos igényeikkel jelentős részü̈k (40-50\%-uk) a megyeszékhely, illetve (a Fejér megyei felhasználók esetében) a föváros valamelyik szolgáltatójához fordul. Részben ennek a térstruktúrának a következménye, hogy a kisvárosokban, illetve különösen a falvakban müködö vállalkozások kevés szolgáltatást vesznek igénybe. A vállalkozók által a megyeszékhely üzleti szolgáltatásairól kialakított kép egyértelmủen pozitív, míg a kisvárosok esetében erösen differenciált. A megye üzleti szolgáltató szektorának strukturális gyengeségei, hiányosságai tehát a falvak (és a kisvárosok) többségében halmozottan (elérhetőségi problémaként is) jelentkeznek.

Az elérhetőségi problémák és az abból eredő feszültségek enyhítése az elektronikus szolgáltatások terjedésével részben megoldható (ugyanakkor nem pótolhatja a személyes kapcsolattartásból, információáramlásból és -értelmezésböl származó 
előnyöket). A felmérésbe bevont szolgáltatók körében csaknem teljes körü az Internet-hozzáférés, és sokoldalú annak kihasználása is. Elsősorban a kommunikációban, a szakmai és piaci információk áramlásában, adatbázisok frissítésében, illetve - szórványosan - a termékforgalmazásban, állásközvetítésben, reklámtevékenységben alkalmazzák a hálózat nyújtotta lehetőségeket, s ezzel maguk a szolgáltatók terjesztik a leggyorsabban és leghatékonyabban a szolgáltatások és felhasználásuk elektronikus formáját. A felhasználók azonban kevésbé rugalmasak, ök túlnyomórészt kommunikációs és pénzügyi e-szolgáltatásokat vesznek igénybe, továbbá üzleti információk gyüjtésére használják a világhálót. Általában passzív szereplői a hálózatnak, saját honlappal kevesen, nagyrészt üzleti, informatikai és kulturális szolgáltatásokat nyújtó szervezetek rendelkeznek. Körük a hozzáférést, illetve az alkalmazást tekintve erösen differenciált: a Fejér megyei vállalkozások nagyobb hányada (53\%) használja, mint a szabolcsiaké (32\%), ugyanakkor erösen felülreprezentáltak a városi székhelyü szervezetek (mindhárom térségben) a felhasználók között. A szférában rejlö lehetöségeket tehát a vállalkozók nagyobb része - elsösorban azok, akik a leginkább rászorulnának - nem képes kiaknázni. Részben az információkhoz való hozzájutás egyenlötlenségei, részben a személyes kapcsolatok fentebb is hangsúlyozott fontossága miatt tehát hosszú távon számolni kell a vázolt területi egyenlötlenségek fennmaradásával.

\section{Összegzés}

A termelöi szolgáltatások körének bővülése és differenciálódása a magyar gazdaság szerkezeti és szervezeti átalakulási folyamatait követve zajlott. A gazdaság új térszerkezetének formálódását, új, dinamikus magterületek felemelkedését és az ország keleti, északkeleti térségeinek leszakadását tükrözik a szektor térben is megjelenö strukturális különbségei, sajátosságai. Ennek a folyamatnak az egyik fontos eleme Budapest üzleti információs monopóliumának az erősödése, de a szolgáltatások piacának hipotézisünkben vázolt (föváros-vidék) dualizmusa a kilencvenes évtized végére kialakult szervezeti és térbeli struktúra leegyszerüsített képének bizonyult. A vidéki székhelyủ gazdasági szervezetek - elsősorban a kis- és középvállalkozások - köre erősen differenciálódott az elmúlt néhány évben: az igénybe

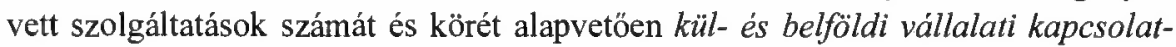
rendszerïk és székhelyük (a szolgáltatások, illetve az azokkal kapcsolatos információk elérhetősége), továbbá (másodlagosan) tevékenységi körïk határozta meg.

Mind a fogyasztói igényeket, mind a termelői szolgáltatások szektorának struktúrảját - sokoldalúságát - tekintve sajátos csoportot alkotnak a megyeszékhelyek. Bár a kilencvenes években formálódó új (szolgáltató) szerepköreik révén domináns szerepet töltetnek be megyéjük gazdaságának müködtetésében, fejlődésük szigetszerü, a szolgáltatók ügyfelei túlnyomórészt a helyi és városkörnyéki szervezetek közül kerülnek ki. A jelenség különösen a gazdaságilag stagnáló-leszakadó térségekben (Baranya, Szabolcs-Szatmár-Bereg) látványos, ahol a megyeszékhelyek (helyi) szolgáltatási piaca viszonylag zárt a nem-rutinszerú tevékenységek 
(pl. a piackutatás, a hirdetés, a speciális pénzügyi és a számítástechnikai szolgáltatások) esetében, ugyanakkor rendkívül csekély mind a megyén kívüli, mind a térség kisebb centrumaiban müködő szolgáltatók súlya a kínálati oldalon. A szektor sajátos elemét alkotó, kutató-fejlesztő szervezeteket és intézményeket segítő szolgáltatások megjelenése csupán szórványos, a felsőoktatási-szolgáltató centrumok gazdaságában zárványként jelennek meg, az intézmények és az ott dolgozó kvalifikált munkaerő kiterjedt nemzetközi kapcsolatrendszere ezért nem vảlhatott ủj helyitérségi gazdasági struktúra alapjává (pl. Pécsett).

A dinamikus, ipari szerkezetváltás sikeres modelljének tekinthető Fejér megyében viszont - az erősödő térségi (észak-déli) különbségek ellenére - sokoldalúbb, (ágazati és térbeli szempontból is) strukturáltabb és nyitottabb vállalati kapcsolatrendszerek formálódtak az elmúlt öt évben, melyekben fontos szerepet töltöttek be a termelói szolgáltatásokat nyújtó szervezetek. A külföldi befektetések, az azokhoz kötődő helyi/térségi vállalkozások körének bövülése és a termelői szolgảltatások fejlődése tehát egymást gerjesztő folyamatnak bizonyult. A vállalati kapcsolatrendszerek nagyobb nyitottsága azonban a szerveződő kapcsolatrendszerek középpontjában álló nagyszervezetektöl, illetve a fövárosi szolgáltatóktól való erősebb külső függést is jelent, éppen a fejlödés fennmaradását hosszú távon biztosító tevékenységi körökben (pl. a müszaki tanácsadás, a kutatás-fejlesztés, a speciális pénzügyi és szoftverszolgáltatások esetében). Amennyiben továbbra is a piaci szereplök töltenek be meghatározó szerepet a szektor valamennyi szegmensében $-\mathrm{s}$ ez a legvalószínübb -, a szolgáltató piac erős tagoltsága és térbeli polarizációja hozzájárul a jelenlegi területi egyenlőtlenségek hosszú távú fennmaradásához.

\section{Jegyzetek}

IAz empirikus felmérést az OTKA (F 029408) támogatásával végeztük el.

2 A "fejlett üzleti szolgáltatások" (advanced producer services, APS) körébe sorolja a nemzetközi szakirodalom azokat a termelői szolgáltatásokat, amelyek túlnyomórészt kvalifikált munkaeröt foglalkoztatnak és amelyek információk átadására, áramlásuk biztosítására irảnyulnak. Az alábbiakban a KSH által kiadott Szolgáltatások Jegyzéke (2000) alapján a következő tevékenységeket soroljuk ide: pénzügyi szolgáltatások, biztositás, pénzügyi tanácsadás, ingatlan-ügyletek bonyolitása, számítástechnikai (hardver-) tanácsadás, szoftver-szolgáltatások, adatfeldolgozás, $\mathrm{K}+\mathrm{F}$, jogi tanácsadás, számviteli szolgáltatások, könyvvizsgálói tevékenység, piackutatás, üzletviteli tanácsadás, müszaki és egyéb szaktanácsadás, hirdetés-reklám, munkaerö-toborzás, oktatás-képzés, titkári-fordítói tevékenység.

${ }^{3}$ A nemzeti és nemzetközi szinten is zajló vállalat-egyesülési folyamatot, illetve nemzetközi vállalati stratégiák kidolgozását siettette az Európai Unióban zajló liberalizációs és jogharmonizációs folyamat is (szabványok egységesítése a szolgáltató szektorban, az iskolai végzettséget igazoló okmányok kölcsönös elfogadása, a telekommunikációs, valamint a munkaerö-, a pénz- és a tőkepiac liberalizációja, a szolgáltatások szabad áramlásának biztosítása) (Daniels 1999).

Az alapítók csaknem kivétel nélkül felsőfokú gazdasági vagy müszaki irányú végzettséggel rendelkez-

5 tek és többségük felelös (felső vagy középszintủ vezetỏi) posztot töltött be korábbi munkahelyén.

Felmérésünk szerint a stabil, kölcsönönös bizalmon alapuló piaci kapcsolatrendszer formálódásának időszakában (elsősorban a kilencvenes évek első felében) a személyes kapcsolatok felértékelődtek, bizonyos értelemben az üzleti etikában mutatkozó hiảnyosságokat pótolták.

${ }^{6} \mathrm{Pl}$. a helyi szolgáltató szektor kínálati információs rendszerét szándékozik bỏvíteni a Pécsi Innovációs Központ keretében tervezett egyablakos szolgáltatási tanácsadó szervezet, amely elsčsorban a vállala- 
tok innovációs, marketing és tanácsadói szolgáltatások iránt felmerülö igényeit igyekszik hagyomá* nyos, illetve internetes információs rendszerével kielégíteni.

Ebbe a csoportba a 10 fỏnél kevesebbet foglalkoztató szervezeteket soroltuk, kiegészítve a $100 \mathrm{M} \mathrm{Ft}$ alatti éves árbevétel kritériumával.

8 Megfigyelhető, hogy a döntően fövárosi és a külföldi piacra „kényszerülő" helyi szolgáltatók (biotechnológai $\mathrm{K}+\mathrm{F}$, Marketing $\mathrm{PR}$, menedzsment tanácsadó és néhány informatikai hálózatépítő) alkottak negatív véleményt a helyi szolgáltató szektorról, a saját vállalkozásaikhoz kapcsolódó felvevơpiaci kapacitást, ill. egyéb háttérszolgáltatásokat hiányolva. A legtöbb válaszadó azonban a szolgáltató szektor hiányosságait Pécs közlekedés-fỏldrajzi szempontú hátrányos helyzetének, az autópálya és repülőtér hiányának róják fel, ami - szerintük - akadályozza a szolgáltatások piacát is felpezsdítő beruházások letelepedését.

\section{Irodalom}

Agnes, P. (2000) The „End of Geography” in Financial Services? Local Embeddedness and Territorialisation in the Interest Rate Swaps Industry. - Economic Geography. 3. 347-366. 0.

Daniels, P. (1991) A World of Services. - Geoforum. 22. 359-376. o.

Daniels, P. (1999) Advanced producer services and economic development. - A new Europe. Economy, society and environment. Wiley\&Sons, Chichester. 127-140. o.

Delgado, A.P. (1995) Producer services demand by manufacturing firms in the NW region of Portugal. Papers of the RSA. Odense.

Döry T. (1998) A beszállítói kapcsolatok és az ipari együttmúködés lehetséges klaszterei a KözépDunántúlon. - Tér és Társadalom. 3. 77-92. o.

Gál Z. (2000) A regionalizmus kihívásai: a magyarországi bankszektor fejlődése és területi struktúrája. Horváth Gy.-Rechnitzer J. (szerk.) Magyarország területi szerkezete és folyamatai az ezredfordulón. MTA RKK, Pécs. 374-396, o.

Geenhiusen, M.-van der Knaap, B.-Nijkamp, P. (1994) Transborder networking: shifts in corporate strategy. - Papers of the RSA. Groningen.

Horváth Gy. (1994) A Dél-Dunántúl nemzetközi versenyképességének elöfeltétele, a technológiai megủjulás. - Tér és Társadalom. 1-2. 37-58. o.

Illeris, S. (1996) The service economy. A geographical approach. Wiley\&Sons, Chichester. 59-74. o.; 132-143. 0 .

Inzelt A. (2001) Kísérlet az innovációk mérésére a szolgáltatási ágazatokban. - Külgazdaság. Április. 35-51. 0 .

Johanisson, B. (1994) Personal networks in emerging knowledge-based firms: spatial and functional patterns. - Papers of the RSA. Groningen.

Michalak, W. (1999) Producer services development problems in new democracies. - A new Europe. Economy, society and environment. Wiley\&Sons, Chichester. 141-156. o.

Nagy E. (1997) Szolgáltató centrumok az Északnyugat-Dunántúlon. - Tér és Társadalom. 1. 109-124. o.

Scott, M.-Storper, A. (1993) The wealth of regions: market forces and policy imperatives in local and global context. Lewis Center for Regional Policy Studies, Univ. of California. L.A.

Tickell, A. (2001) Progress in the geography of services II: services, the state and the rearticulation of capitalism. - Progress in Human Geography. 2. 283-292. o.

Williamson, A. (1985) The economic institutions of capitalism. The Free Press, New York.

Wood, A. (1994) Inter-firm Networks and the Development of Local Economies. - Papers of the RSA. Groningen. 